\title{
Obstacles to torture rehabilitation at Guantánamo Bay
}

\author{
James Connell JD*, Alka Pradhan JD, LLM*, Margaux Lander BA*
}

\section{Key inssues:}

- The United States has a legal duty to provide rehabilitation to the current detainees under international law.

- The conditions under which detainees are held make it impossible to physically or mentally rehabilitate them, or even to provide them with basic medical assistance.

- Innovative ways must be found to try to assist with rehabilitation when the prospect of being set free remains elusive.

\section{Abstract}

This article sets out the legal duty of the United States of America to provide victims of torture and cruel, inhumane and degrading treatment (CIDT) the right to full rehabilitation under international law, including those still detained at the facility at Guantánamo Bay. After an examination of some of the torture methods used on these detainees, while they were in the custody of the CIA and arguably afterwards, it goes on to indicate the current obstacles to rehabilitation, including on-going incarceration, lack of impunity, classification of medical documents and limited access to non-military staff. Limited options for possible psychological assistance towards the right to rehabilitation are considered.

${ }^{\star}$ United States Department of Defense, Military Commissions Defense Organization.

This article has been redacted by the United States military authorities before being published.
Keywords: Torture, International Law; prisoners, Cruel, Inhuman, or Degrading Treatment, detention, security, rehabilitation, survivors, Guantánamo.

\section{Introduction}

In the early 2000's, the United States adopted a policy of using torture and other cruel, inhuman, and degrading treatment (CIDT) against Muslim men considered to be terror suspects. The techniques were initially authorized for use by the Central Intelligence Agency, and later "bled" into detention operations conducted by the Department of Defense (DoD) in Afghanistan, Iraq, and Guantánamo (Constitution Project, 2013). Although President George W. Bush never acknowledged that the techniques used during brutal CIA interrogations constituted torture or CIDT, President Obama finally admitted in 2014 that, "We tortured some folks." That same year, a declassified, redacted Executive Summary of a Congressional investigation documented some of the shocking details of the CIA's "Rendition, Detention, and Interrogation" program (SSCI, 2014).

The techniques certainly did not "hide in a vault at the CIA" (Biswas \& Zalloua, 2011, p.27). Human beings tortured other human beings - yet under the guise of national security, the torturers have enjoyed impunity. One of them (Dr. James Mitchell, one of the psychologists who developed the CIA program) is currently promoting a memoir about his work with the CIA, and elaborates on his view of the characters and motivations 
of the detainees whom he tortured. Meanwhile, many of the survivors remain imprisoned at Guantánamo Bay and unable to speak freely about their suffering. The continuing effects of torture on these men, and their lack of access to medical treatment, are the subjects of this article.

The United States has signed and ratified the UN Convention Against Torture ("CAT") which mandates treatment for all survivors of torture, including those at Guantánamo Bay (Chlopak, 2002). Article 14 of the CAT explicitly requires that every state party ensures that torture victims have "enforceable rights" to compensation, which includes "the means for as full rehabilitation as possible." The Committee against Torture ${ }^{\mathrm{i}}$ has explained that the obligation of States parties to provide the means for 'as full rehabilitation as possible' refers to the need to restore and repair the harm suffered by the victim whose life situation, including dignity, health and self-sufficiency may never be fully recovered as a result of the pervasive effect of torture (Convention against Torture, 2012, General Comment No. 3). ${ }^{\text {ii }}$ Such rehabilitation "should be holistic and include medical and psychological care as well as legal and social services" (CAT 2012, General Comment No. 3). The CAT therefore recognizes an enforceable right of all torture survivors to receive rehabilitation, and a legal duty of the state to provide such rehabilitation. Importantly, the free-standing

\footnotetext{
${ }^{\mathrm{i}}$ The group of experts whose mandate is to interpret the treaty, receive and respond to periodic reports by state parties, and receive individual communications regarding potential violations by state parties.

ii One of the many legal controversies at the United States Military Commissions at Guantánamo Bay is the enforceability of the Convention Against Torture. One military commission has ruled that although the United States is bound by the Convention Against Torture, tortured individuals cannot enforce its provisions (United States Military Commission 2013).
}

right to torture rehabilitation has been interpreted as "a universal duty to provide [victims] with health care and reintegrative services, without considerations as to whether formal complaints or court decisions have been made, to who was responsible for the torture or where it happened" (Sveass, 2013). Recalling that the United States acknowledged the application of the CAT to the territory under its control at Guantánamo Bay in 2014, although the government insists that it does not create rights of action for Guantánamo detainees. (United States v. KSM, AE200II 2013). Nevertheless, the application of the CAT at Guantánamo legally means that regardless of "belligerent" or "clearance" status, every torture victim at Guantánamo must be given access to holistic rehabilitation by the government. That has not been the case.

This article will summarize some of the obstacles to treatment of Guantánamo prisoners suffering from the effects of their torture and CIDT, and offer suggestions for amelioration of these obstacles. This article will not address the issue of treatment of those men who have been released or resettled from Guantánamo, who face overwhelming but distinct challenges.

\section{Background: The torture techniques}

Beginning in 2002, the United States government actively sanctioned "enhanced interrogation techniques" for use on terror suspects, which included techniques long-recognized by international law to constitute torture or CIDT. In order to authorize the use of such techniques on terror suspects, members of the Bush administration issued legal memoranda disqualifying the application of 18 U.S.C. paras 2340-2340A, the United States anti-torture statute. In August 2002, then-Assistant Attorney General Jay Bybee 
stated in a memo to White House Counsel Alberto Gonzales that "for an act to constitute torture as defined in Section 2340, it must inflict pain that is difficult to endure. Physical pain amounting to torture must be equivalent in intensity to the pain accompanying serious physical injury, such as organ failure, impairment of bodily function, or even death." (Bybee, 2002). Notwithstanding the comparison of "physical pain" to medical death, Mr. Bybee continued his analysis with a second memo enumerating the techniques to be used as " 1 . attention grasp, 2. walling, 3. facial hold, 4. facial slap (insult slap), 5. cramped confinement, 6 . wall standing, 7 . stress positions, 8. sleep deprivation, 9 . insects placed in a confinement box, and 10 . the waterboard." (Bybee, 2002). All of these techniques were approved by Bybee as consistent with the U.S. anti-torture statute. The torture of detainees was not merely sadism; the explicit goal was to achieve "learned helplessness" of the prisoners. "The goal of interrogation is to create a state of learned helplessness and dependence conducive to the collection of intelligence in a predictable, reliable, and sustainable manner" (CIA, 2004, p.2). Mitchell has described it as involving classical and avoidance conditioning (Mitchell, 2016).

Two memos issued in 2005 by Steven Bradbury, former Acting Assistant AttorneyGeneral, re-evaluate the CIA's interrogation

\footnotetext{
iii Bradbury memo 1: $900 \mathrm{kcal} /$ day plus $10 \mathrm{kcal} / \mathrm{kg} /$ day, multiplied by 1.2 for a sedentary detainee.

iv Used to cause "psychological discomfort," with ambient temperature to be kept at 68 degrees Fahrenheit and "no sexual abuse or threats of sexual abuse permitted." As we now know, this stricture was not followed.

${ }^{v}$ Standing 4-5 feet away from a wall with arms outstretched to the wall, without permission to move hands or feet. There is no maximum time period guidance given for use of this technique.
}

techniques. In the first memo, Bradbury slightly modified Bybee's assessment of the legal standard, stating that techniques violating the anti-torture statute must cause "severe physical or mental pain and suffering," but dropping the "organ failure" level of severity in the definition. (Bradbury, 2005a). Bradbury's first memo, entitled “Application of 18 U.S.C. \$\$ 2340-2340A to Certain Techniques That May Be Used in the Interrogation of a High Value Al Qaeda Detainee," enumerates a slightly different list of techniques, however - giving rise to questions regarding how the techniques changed in the intervening years: 1 . Dietary manipulation iii $^{\text {ii }}$ 2. Nudity ${ }^{\text {iv }}$, 3. Attention grasp, 4. Walling, 5. Facial hold, 6. Facial slap (insult slap), 7. Abdominal slap, 8 . Cramped confinement, 9. Wall standing ${ }^{\mathrm{v}}, 10$. Stress positions, 11. Water dousing ${ }^{\mathrm{vi}}$, and 12 . Sleep deprivation. ${ }^{\text {vii }}$ The last two techniques were particularly damaging: the redacted Executive Summary of the SSCI Report states that " $[\mathrm{t}]$ he waterboarding technique . . . was physically harmful, inducing convulsions and vomitings ... Internal CIA records describe the waterboarding of Khalid Sheikh Mohammad as a 'series of near-drownings,"” which would seem to place them legally within "organ failure" level of physical disruption (SSCI, 2014, p. 3).

The second Bradbury memo is entitled “Application of 18 U.S.C. \$\$ 2340-2340A

\footnotetext{
vi 20 minutes duration of pouring allowed if water was 41 degrees Fahrenheit; 40 minutes with water temperature of 50 degrees; or 60 minutes with water temperature of 59 degrees.

vii Maximum duration allowed was 180 hours before detainee had to be allowed to sleep "without interruption for at least eight hours.” According to the SSCI Redacted Executive Summary, "CIA interrogators subsequently reported subjecting Adnan al-Libi to sleep deprivation sessions of 46.5 hours, 24 hours, and 48 hours, with a combined three hours of sleep between sessions." (p.134).
} 
[the United States anti-torture statute] to the Combined Use of Certain Techniques in the Interrogation of High Value CIA Detainees" (Bradbury Memo to Rizzo on Combined Use, 2005). This memo reflects reality at the CIA black sites, more than any of the previous memos, in that it contemplates (and provides legal authorization) for use of the above techniques in combination, which is how the CIA had applied them from the beginning of detention in 2002. As the SSCI said in the redacted Executive Summary of its report on CIA rendition:

"Beginning with the CIA's first detainee, Abu Zubaydah, and continuing with numerous others, the CIA applied its enhanced interrogation techniques with significant repetition for days or weeks at a time. Interrogation techniques such as slaps and 'wallings' (slamming detainees against a wall) were used in combination, frequently concurrent with sleep deprivation and nudity. Records do not support CIA representations that the CIA initially used an 'open, non-threatening approach,' or that interrogations began with the 'least coercive technique possible' and escalated to more coercive techniques only as necessary (SSCI, 2014, p. 3)."

To demonstrate the combined use of torture techniques, the SSCI describes CIA sleep deprivation as "keeping detainees awake for up to 180 hours, usually standing or in stress positions, at times with their hands shackled above their heads. At least five CIA detainees experienced disturbing hallucinations during prolonged sleep deprivation, and, in at least two of those cases, the CIA nonetheless continued the sleep deprivation" (SSCI, 2014, p. 3).

We also know that multiple techniques were used that had not been "legally authorized" by the U.S. Department of Justice. Multiple detainees were anally penetrated using "the largest Ewal [sic] tube" CIA officials had, for the sole purpose of demonstrating the "interrogator's 'total control"' over the tortured men, in accordance with the "learned helplessness" model designed by Mitchell and his colleague Bruce Jessen (SSCI, 2014, pp. 100, 82). During anal penetration of detainees, CIA officials would sometimes insert pureed food items, including "hummus, pasta with sauce, nuts, and raisins" (SSCI, 2014, p. 100).

The CIA also used loud music or white noise, constant light, and shaving as extralegal techniques. The SSCI recounts how despite the CIA's assurances that shaving was only conducted upon intake and was not punitive, "Detainees were routinely shaved, sometimes as an aid to interrogation; detainees who were participating at an acceptable level were permitted to grow their hair and beards" (SSCI, 2014, p. 429). The CIA also "use[d] music at decibels exceeding the representations to [the Department of Justice]," and "numerous detainees were subjected to the extended use of white noise" (SSCI, 2014, p. 429). Again, this clearly violated the prohibition detailed in Bradbury's memo on "severe mental pain or suffering."

The United States government claims that use of torture techniques ended when the CIA detainees arrived at Guantánamo Bay in September 2006. However, this claim discounts the separate allegations of torture and CIDT during at least the first five years of military detention at Guantánamo (2002-2007), and also ignores the allegations by some former CIA detainees that use of torture techniques has continued at Camp 7, where they are held. These allegations are detailed below. It also ignores that under the CAT, failure to provide torture rehabilitation constitutes a continuing treaty violation that must be addressed. 


\section{Current conditions of the tortured at Guantánamo}

Despite an effort to reduce the prison population at the close of the Obama Administration, 41 prisoners remained at Guantánamo on January 20, 2017. These prisoners include some of the most well-known of the men to experience U.S. interrogation methods: Abd al Rahim al Nashiri, Abu Zubaydah, Khalid Shaikh Mohammad, and Mohammad al Qahtani. They also include the authors' client, Ammar al Baluchi.

As al Baluchi has described, "Years later I still have trigger responses to sound and scents among other things. The intense feelings of the torture flood in and are often unexpected when they come. The threats and fear continue to plague me daily making it difficult to not remember the torture that I still endure" (Amnesty International, 2017, p.19).

Although all of the Guantánamo prisoners are Muslim, they are otherwise culturally diverse. The 41 prisoners come from 13 countries (Rosenberg, 2017). Many are Arabs, but many are not. Many speak Arabic as their first language, but many do not. Many have post-secondary education, but many do not. This diversity of backgrounds has resulted in wide variations in the presentation of trauma and impact on mental health (Sayed 2003).

In 2016, New York Times reporters conducted the most comprehensive review of the mental health consequences of the U.S. government's interrogation methods to date. The New York Times concluded that, "After enduring agonizing treatment in secret C.I.A. prisons or coercive practices at the military detention camp at Guantánamo Bay, Cuba, dozens of detainees developed persistent mental health problems ...." (Apuzzo, Fink, \& Risen 2016). It found that, "At least half of the 39 people who went through the C.I.A.'s 'enhanced interrogation' program, which included depriving them of sleep, dousing them with ice water, slamming them into walls and locking them in coffinlike boxes, have since shown psychiatric problems." (Apuzzo, Fink \& Risen 2016).

Although reviews of detainee medical records are severely limited by many of the factors discussed in this article, one record review in 2011 found that each of the nine reviewed "detainees continues to experience severe, long-term and debilitating psychological symptoms that are likely to persist for many years, and possibly a lifetime" (Iacopino \& Xenakis, 2011, p.4). Declassified portions of a classified psychological assessment of al Nashiri show that he shows long-term effects of his torture, including continuing nightmares, a phobia of water, and other signs of post-traumatic stress (Savage, 2017). Other detainees, including al Baluchi, have complained of similar, or worse, sequelae (Amnesty International, 2017, p. 19).

\section{Obstacles to rehabilitation at Guantánamo}

Some of the obstacles to torture rehabilitation at Guantánamo are the same/similar to those faced by treatment seekers and providers the world over. For example, “[d] escribing the physically and psychologically painful experiences of being tortured can itself be an exceptionally painful and overwhelming process" (Pope, 2012, p.421). The brain organizes itself around "a presumed permanent need for defense," (Elbert et al., 2011, p.167), and torture survivors often simply cannot recall the details care providers and attorneys want to know.

Guantánamo does, however, present a number of rare or even unique challenges to the torture survivors imprisoned there: 
Threatening environment

The first and most obvious obstacle to torture rehabilitation at Guantánamo is that the torture survivors are also prisoners, as the United States continues to incarcerate the men, ostensibly under the law of war. Eight men are charged and face proceedings in a military commission; two others have been convicted but not yet sentenced; and another is serving a sentence while his case is on appeal. The other thirty men do not face charges. This dual role of detainee/prisoner and torture survivor is a result of the policy decision to use torture on terror suspects. "Torture is also justified by the crimes and identities of the terrorists - they are the 'worst of the worst. . . .' But while the bodies of prisoners may be subject to violence for the extraction of information, they [must now also be] objects of care" for the government, which is inherently contradictory. (Biswas \& Zalloua, 2011,103).

Some suggest that torture rehabilitation is impossible in this prison environment. For example, prominent torture rehabilitation center Freedom from Torture has proposed, "the environmental context in which rehabilitative services are offered must be safe and stable" (PRI, 2013). Guantánamo fails both the objective and subjective components of these criteria, given that prisoners and their medical care remain in the complete control of the Department of Defense. Indeed, most of the factors mentioned in this article could be viewed as demonstrating the unsafe environment and instability of Guantánamo as a context for torture treatment.

Others may suggest that torture treatment at Guantánamo would be counterproductive. "If the government does not change and/or if, as happened in Chile and Argentina, those committing these acts receive immunity from prosecution, any modicum of rehabilitation for the victims is compromised by the daily reminder of their own powerlessness in the face of the continuing power of their tormentors. The psychological consequences of impunity exacerbate the damage" (Fields, 2008, p. 154).

Although these concerns are real, there are still two reasons to consider the viability of any torture treatment that might be possible. First, the U.S. legal position that it has the right to incarcerate the Guantánamo prisoners under the law of war does not relieve the United States of the duty, or the prisoners of the right, of torture rehabilitation under international law. Second, the issue of incarcerated torture survivors is not unique to Guantánamo. "There is not a good methodology to calculate the magnitude of the problem of torture worldwide, but the numbers of torture survivors should be several million" (Quiroga \& Jaranson, 2005, p. 70). The United Nations Special Rapporteur on Torture visit prisons around the world and are mandated to submit urgent appeals regarding the torture of prisoners or lack of medical treatment for tortured prisoners. Therefore, although Guantánamo may be a unique prison setting, methods of verifiably ending torture and effectively treating torture survivors within prison conditions must be developed.

\section{Isolation}

Guantánamo prisoners are currently divided into two groups for detention purposes. Approximately 15 so-called "High Value Detainees" are generally detained in Camp 7, which a reviewing admiral in 2009 said was "effectively" a "supermax facility" (Walsh, 2009). The remaining approximately 26 prisoners are in [other camps], which the reviewing admiral described as "designed by U.S. standards for maximum security detention" (Walsh, 2009). An officer at Guantánamo has testified that it is not 
possible to earn a transfer from Camp 7 to [another camp] through good behavior (United States v. KSM, AE448 2016, p.6).

Two declassified sources have demonstrated at least some involvement of the CIA in Camp 7 beyond the prisoners' transfer from black sites in 2006. First, the SSCI wrote, "After the 14 CIA detainees arrived at the U.S. military base at Guantánamo Bay, they were housed in a separate building from other U.S. military detainees and remained under the operational control of the CIA" (SSCI, 2014, p.160). Second, the CIA in 2016 declassified a highly redacted Memorandum of Agreement between the CIA and Department of Defense regarding Camp 7 (Memorandum of Agreement, 2006). Among other things, this "sets out the duties and responsibilities of DoD and CIA concerning DoD's detention of certain individuals designated by the President to be transferred to the control of the Secretary of Defense, who were captured in the War on Terrorism and who have conducted and/or have engaged in planning for, terrorist acts against US persons or interests" (Memorandum of Agreement, 2006).

Given that the very existence of Camp 7 was classified until 2008 very few details about it exist publicly (Rosenberg, 2008). One of the authors (James Connell) is among the few who have been inside Camp 7, pursuant to a military commission order, but classification restrictions prevent discussion of details. Two prisoners, however, have testified about their perception that torturous conditions mimicking the CIA black sites continue in Camp 7.

Ramzi bin al Shibh is a 45 -year-old Yemeni man accused of participation in the planning of the 9/11 attacks (National Commission on Terrorist Attacks, 2004). Bin al Shibh has consistently accused U.S. authorities of subjecting him to "sounds and vibrations" in his cell at Camp 7 that prevented him from sleeping and affected his health. In Mitchell's 2016 book, he discussed using vibration on bin al Shibh (allegedly by a piece of heavy machinery) at the black sites (Mitchell, 2016). Nevertheless, Guantánamo authorities have denied bin al Shibh's claim, and in 2013 prosecutors used bin al Shibh's allegation to seek evaluation of his mental state (Ramstack, 2013). The evaluators could not reach a conclusion given the information available to them, which at the time did not include Mitchell's book, but would have included bin al Shibh's CIA medical records, which are in the government's possession and may have included reference to the vibration technique at the black sites (Serrano, 2014).

In February 2016, bin al Shibh testified before the military commission about what he deemed systematic and intentional "noise and vibrations" inside Camp 7. During his testimony, he said that when he protested about the sounds, a U.S. Navy psychiatrist drugged him. He described being drugged: "[T] he worst time in my life was at that moment when they gave me injection, more worse than black site. Black site was abuse, was physical abuse, was torture. But this one, the injection without any reasons, that was the worst thing I have ever went through" (Transcript, Testimony of Ramzi bin al Shibh, 2016, p.11142).

Later, in 2016, another prisoner known as Hassan Guleed also testified about the conditions of confinement at Camp 7. He said, "we have mental [torture] here at Camp 7 ... the noises are different, sometimes hammering, high-pitched noises, chemical smell... for six years" (Transcript, Testimony of Hassan Guleed Dourad, 2016, p.12180). Another element that Guleed revealed was the 2009 opening of the so-called "beanholes" - the slots in each detainee's door through which prison meals 
are passed (2016, p.12176). Guleed stated that prior to 2009, Camp 7 prisoners could not open or communicate with one another through the beanholes. Prisoners are currently allowed to open their beanholes.

\section{Untrained legal teams}

This strict isolation means that generally the only people, other than prison staff, who have regular access to Guantánamo prisoners are each prisoner's legal team, if the prisoner has one. Legal teams are provided by the Department of Defense's Military Commissions Defense Organization, for those detainees in active trial proceedings at Guantánamo. The core members of the legal teams are attorneys, paralegals, investigators, intelligence analysts, and linguists. No legal team is allocated an independent psychologist for their client, although some teams have succeeded in obtaining funding for nonGuantánamo -based security-cleared psychologists to meet occasionally with their clients. The legal teams themselves are not professionally trained in psychological issues, and are required to focus on litigation rather than treatment. In many ways, the legal teams are woefully unprepared to work with survivors of torture.

Many of the 41 prisoners remaining at Guantánamo - those not in active military commission proceedings - simply do not have a legal team. The United States government supports some representation: various Federal Public Defender offices, as well as non-governmental organizations like Reprieve, the Center for Constitutional Rights, the American Civil Liberties Union, pro bono lawyers and law firms representing prisoners seeking writs of habeas corpus in federal court, or other administrative or judicial relief. These legal teams have varying mandates and levels of resources.

The identities of these legal teams can present severe challenges to building a trusting relationship. As Sveaass notes, the following factors are of crucial importance: "The level of confidence that the person has with respect to receiving rehabilitation services offered by the authorities, the question as to whether the person still lives in the state where violence has been committed and whether the necessary steps have been taken with regard to complaints, assessments and documentation" (Sveass 2013). Those who work with survivors of torture must build on a foundation of trust, respect, believability, and sensitivity, recognizing the political context of torture (Engstrom \& Okamura, 2004). Not only are Guantánamo prisoners still in the custody of the state that tortured them, without serious legal remedy for their acknowledged torture - but the Military Commission Defense Organization is primarily composed of U.S. military personnel. Many of its civilian and contract employees have military or intelligence backgrounds similar to those of officials who initially tortured the prisoners at the black sites or at Guantánamo. All lawyers at Guantánamo must be able to obtain security clearances, which means that they must be U.S. citizens. Prisoners often suspect the loyalty or motives of their appointed legal teams. Some prisoners, lacking trust in the American legal system and their American lawyers, have declined representation altogether.

Beyond their identities, the military commission legal teams are by definition focused on legal matters, and lack psychological resources or training. Although the standard of practice in capital cases within the United States requires at least one team member qualified to screen for psychological issues, military commission funding authorities have been slow to support psychiatric or psychological expert services. Some military 
commission legal teams include a consultant psychologist or psychiatrist, but these experts must generally focus on evaluation rather than treatment.

\section{A predominantly Western approach to medical treatment}

As briefly mentioned, in order to be allowed contact with a Camp 7 prisoner (those prisoners tortured by the CIA at the black sites) a person generally must have a security clearance at the Top Secret/Secure Compartmented Information/Special Access Program level. Guantánamo authorities only allow contact with Camp 6 prisoners to people with Secret level clearances. These security restrictions mean that every person who has contact with Guantánamo prisoners is necessarily American.

American medical, psychological, and legal professionals, however well-meaning, do not align with the physical and mental illness conceptualizations of all of the culturally and ethnically diverse prisoners at Guantánamo (Sayed, 2003). "Culture has a major influence on how we understand, express, and resolve mental distress and medical symptoms" (Quiroga \& Jaranson, 2005, p. 41). For example, devout Muslims may discuss some of their symptoms in terms of the effects of Jinn or in distinction from the effects of Jinn. ${ }^{\text {viii }}$ It is widely accepted amongst Muslims that Jinn are real creatures that are capable of causing physical and mental harm, such as possession (Khalifa \& Hardie, 2005). Many Muslims also believe that Jinn can enter the human body and cause mental illness. Symptoms of Jinn possession could be forgetfulness, lack of energy and morbid fears (Khalifa, Hardie, Latif, Jamil, \& Walker, 2011). American professionals, particularly the detention authorities at Guantánamo, have been quick to dismiss these complaints because they are expressed in an unfamiliar cultural vocabulary. In 2014, hunger striker Abu Wa'el Dhiab challenged what he deemed to be inhumane force-feeding procedures at Guantánamo, and was ordered to undergo physical and psychological evaluations by independent (non-Guantánamo-affiliated) doctors. Dhiab had numerous problems with his legs and back, including broken ribs from being forcibly extracted from his cell, that required the use of a wheelchair during his 13 years at Guantánamo. ${ }^{\text {ix }}$ While the U.S. government said derisively that Dhiab suffered only "from self-described 'genies' in his legs," (despite giving him morphine for his pain), in fact his psychological report stated that:

"There is no evidence of hallucinations, delusions, or illusions. He refers to cultural traditions of 'spirits or jins' that can influence health and state of mind. His descriptions are appropriate to his culture and his physical complaints.

Cognitive processes are intact (Xenakis

Expert Report, 2014)"

Many other prisoners do not wish to discuss their symptoms because they do not think they will be believed - or worse, they believe that they will be drugged into silence as Bin al Shibh has been. The New York Times interviewed one Guantánamo doctor who recalled prescribing "powerful anti-psychotics" after prisoners complained of being "plagued by jinns," even as she wondered, "Are we doing the right thing?" (Fink 2016).

\footnotetext{
viii Jinn are described in Islamic writings as created beings, that can see us but cannot be seen by humans. The origins of Jinn can be traced back to the Qur'an, originating before mankind from "smokeless flame of fire." Jinn are said to inhabit dark places such as graveyards and caves and are known for tempting or seducing mankind to stray from Allah (Khalifa \& Hardie, 2005)

ix http://www.courthousenews.com/genies-cited-in-oncesecret-briefon-wheelchair-ban-at-Guantánamo /.
} 
Cultural humility is critical, and service providers need to acknowledge the "baggage they bring of their own cultures - their own ethnic backgrounds along with the culture of medicine - to the patient's bedside, and that these may not necessarily be superior" (Fadiman, 2012).

In a limited capacity, there may be opportunities for Guantánamo prisoners to speak with linguists who share their language and even occasionally their cultural heritage. However, these linguists are not trained mental health providers and may not know the essential terminology or concepts needed to discuss symptoms and issues in a sensitive manner (Pope, 2012). Most importantly, their mandate is legal, rather than medical, and they are simply unequipped and unable to provide any kind of rehabilitation.

\section{Classification of medical information and treatment}

One obstacle unusual to Guantánamo is the use of security classification to limit the transfer of medical information. The CIA high-value detainee program was "extraordinarily compartmentalized in order to maximize secrecy" (Khalili, 2013, p. 151), and much about the program remains classified, including the locations of the black sites and the personnel involved in the commission of torture. As a result, U.S. authorities have applied numerous classification regimes at Guantánamo, making the transfer of information to, from, and about prisoners very difficult.

A complex regime governs information transfer at Guantánamo, with different rules for prisoners in various statuses. Former CIA prisoners have no access to telephone or ordinary mail, except to contact their families through the International Committee of the Red Cross. Other prisoners have the ability to arrange occasional telephone calls with their attorneys and family members,

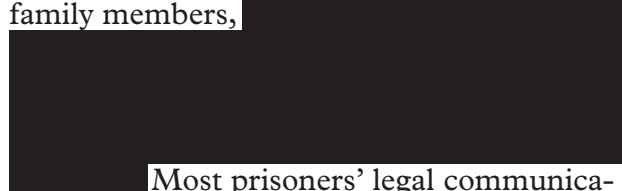
tions fall under protective orders issued by the District Court in D.C. and Joint Task Force-Guantánamo Bay, which provide that all of their communications are presumed classified until declassified by a Privilege Review Team (Eisenberg, 2009).

Until recently, the prisoners charged with offenses in a military commission were governed by a separate set of orders, which were generally less restrictive. Those military commission orders treated prisoner communications as unclassified unless they concern specific torture-related categories (primarily location and personnel information). The categories did not include torture techniques a prisoner experienced or their symptoms meaning that prisoner communications about their torture and enduring injuries were generally unclassified. The orders allow the attorneys limited authority to handle unclassified information without supervision, and provided a mechanism for the attorneys to obtain classification review in case of doubt.

It was therefore possible for attorneys to share those torture details with treatment providers who could correspond with some Guantánamo prisoners through their attorneys or even offer remedies - as two of the authors have previously done. Such correspondence would necessarily be slow and limited by classification concerns, but could and did take place.

In June 2017, however, the chief military commission judge, James Pohl, ruled that even unclassified legal mail from the former CIA prisoners could no longer be shared with members of the public, including potential outside caregivers, such as inde- 
pendent organizations who routinely provide care for the imprisoned. Therefore, even that limited avenue of treatment for Guantánamo prisoners continuing to deteriorate from the effects of their torture may now be closed.

The following statement from $\mathrm{Mr}$. al Baluchi is an example of torture description that may be useful for rehabilitation provid-

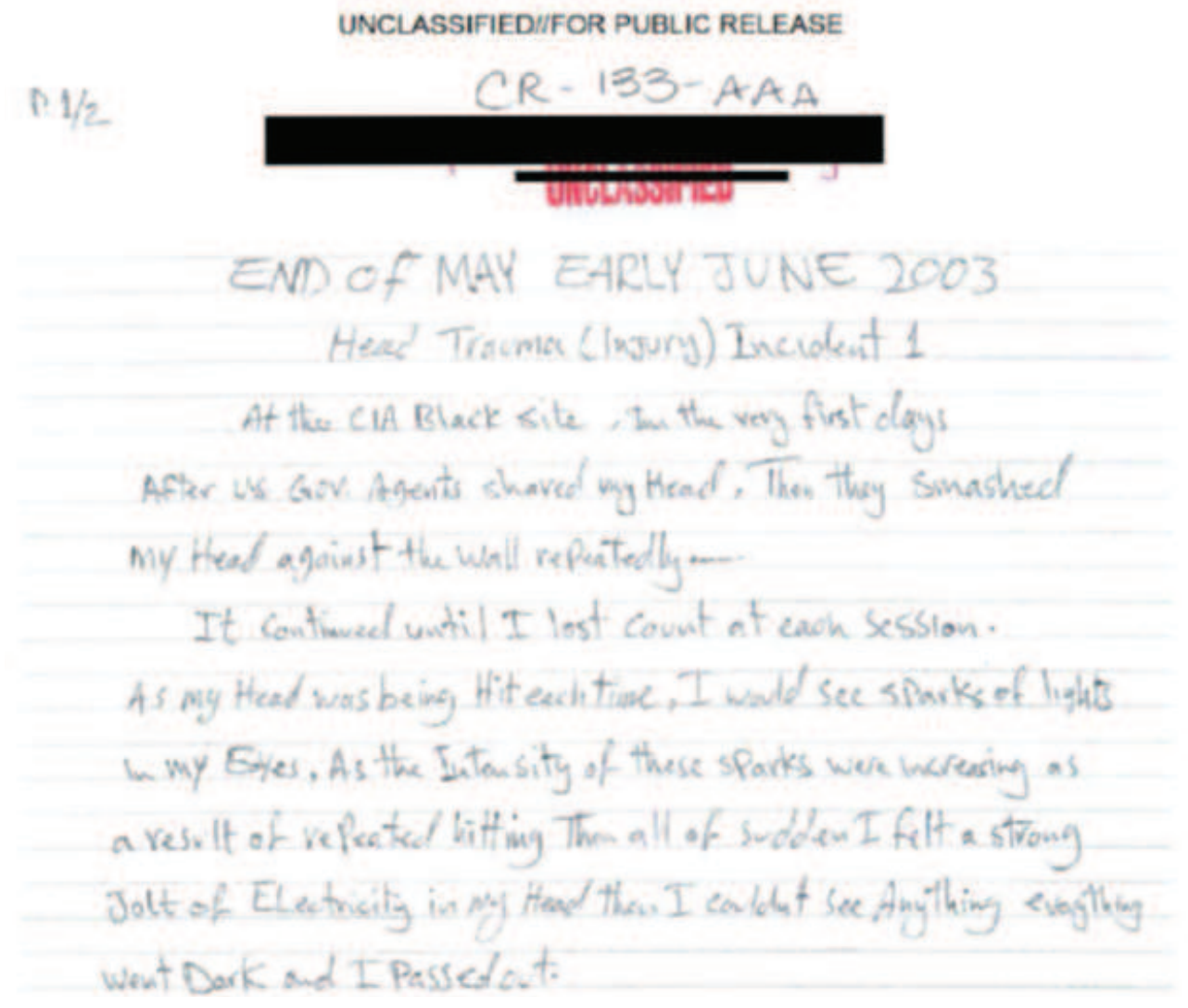

ers. This statement had previously been cleared for public release. New statements may not now be shared with the public:

\section{Medical infrastructure}

Medical care of the prisoners is, in many ways, irreversibly damaged through destruction of the provider-patient relationship by doctors' roles in the CIA torture.

The prisoners who still seek rehabilita- tion from their American jailers face an uphill struggle with poorly-trained personnel and classification barriers.

Psychologists in torture program

It is important to understand that the goal of CIA torture and CIDT was not short-term information, but rather long-term compliance. The CIA view was that, "Effective interrogation is based on the concept of using 
both physical and psychological pressures in a comprehensive, systematic, and cumulative manner to influence [prisoner] behavior, to overcome a detainee's resistance posture" (CIA, 2004, p. 1). "Refined through years of practice, the agency's psychological paradigm came to rely on a mix of sensory overload and sensory deprivation for a system attack on all human stimuli via seemingly banal procedures - manipulation of heat and cold, light and dark, noise and silence, isolation and the intense interrogation" (McCoy, 2012, 53). The CIA thus specifically intended to alter the long-term psychological make-up of their prisoners.

One participating psychologist has made clear the participation of medical doctors and psychologists in the CIA program (Mitchell, 2016). The Guantánamo Behavioral Science Consulting Teams also included psychologists. Given the participation of psychologists in the original abuse, the process of torture assessment outside the context of a trusting relationship itself evokes echoes of the torture (Pope, 2012). "Some of the acute neurobiological responses to trauma may facilitate the encoding of traumatic memories. The memories of traumatic experiences remain indelible for many decades and are easily reawakened by all sorts of stimuli and stressors" (Charney, 1993).

Evidence suggests that interrogators used techniques of sexual, religious and moral humiliation to break down the prisoners. Many of the techniques deliberately degraded the Islamic faith, for example, violating explicit taboos relating to women, pornography and homosexuality. "Torturers targeted degradation of subject: sexual violations and humiliations ... [and] desecration of religious objects and rituals" (Bufacchi \& Arrigo, 2006, p. 356). In particular, interrogators used anal penetration as a tool of control, sometimes causing long-term damage to the survivors (SSCI, 2014).

Cultural norms mean that acknowledging sexual victimization from same- or oppositesex interrogators is especially difficult for Muslims imprisoned at Guantánamo (Pope, 2012). "Implicit in these scenarios is the idea that sexual torture is a source of particular humiliation and un-manning for Muslims and that sexual freedoms are a particular treasure of the West" (Bhattacharyya, 2008, 13). Among other symptoms, survivors of sexual trauma report deep feelings of shame and guilt (Oosterhoff et al., 2004, 71). Only a particularly sensitive and trusted professional can properly elicit and evaluate the sexual trauma of some of the Guantánamo prisoners.

\section{Medical care at Guantánamo}

Joint Task Force-Guantánamo Bay, which runs the prisons, includes abundant medical and psychological staff, but does not include professionals specializing in torture rehabilitation. Assessing and treating torture survivors is a highly specialized field requiring particularized competence (Pope, 2012).

According to a number of reports, medical and psychological personnel do not ask their patients at Guantánamo what happened to them during interrogation. Captain Albert J. Shimkus, USN (retired), commanded the Guantánamo hospital, told The New York Times that his medical staff "was dealing with the consequences of the interrogations without knowing what was going on." (Apuzzo, Fink, \& Risen, 2016).

In one of the rare studies of Guantánamo prisoner medical records, Iacopino \& Xenakis reviewed the medical records of nine prisoners and compared them with other evidence of the prisoners' abuse. They observed that, "The medical doctors and mental health personnel who treated the detainees at GTMO failed to inquire and/or 
document causes of the physical injuries and psychological symptoms they observed" (Iacopino \& Xenakis, 2011, p. 4).

Another reason a therapeutic relationship between military psychologists and Guantánamo prisoners is virtually impossible is the lack of respect for a prisoner's right to medical privacy. A prior policy required medical practitioners to provide medical information to the military and CIA on request (Bloche \& Marks 2005). Prosecutors at Guantánamo claim the right to inspect prisoners' medical records, and have done so on many occasions. Furthermore, prison authorities deny the prisoners access to their medical records on the basis that the medical records are classified. Even attorneys for the prisoners cannot access full versions of the medical records. The United States government has created a situation where the legal authorities seeking the execution (in some cases) of the prisoners can access their full medical files, but the putative patients and their defense teams cannot. It should be noted that this engenders numerous legal issues beyond failure to provide access to rehabilitation.

Other limitations on an effective and appropriate doctor-patient relationship include frequent rotations of staff, limited access to historical and personal information/ background. As active-duty military, the medical providers at Guantánamo serve limited rotations, both as part of ordinary military practice and, probably, as an anti-elicitation measure. These providers do not have access to any medical records from before September 2006. In fact, the authors have actually seen unclassified medical records describing 6 September 2006 (the date of transfer from black sites) as the patient's birthday.

\section{Options for torture rehabilitation?}

Given the massive obstacles to even basic medical treatment at Guantánamo, the possibilities for meaningful torture rehabilitation are miniscule. However, small opportunities to alleviate the ongoing torture effects may exist. Under current law, these possibilities for treatment would have to take place outside the United States and take into account the security structure of Guantánamo imprisonment.

Treatment within the United States is impossible at this time. Current U.S. law prohibits the transfer of Guantánamo prisoners to the United States, even for medical treatment. This law could change, but would require a change in political currents.

The holistic treatment approach used by many treatment centers is also not possible at Guantánamo. Many people involved in rehabilitation of torture victims advocate holistic approaches which seek to restore the individual's functioning in the context of family and community (Kira 2002). This approach is precluded by the restrictive environment at Guantánamo, which permits only specific group classes in [the camps], no classes in Camp 7, and only rare communication with family, largely via letters.

One possible approach might be narrative exposure therapy (NET). NET is based on Testimony Method (Cienfuegos \& Monelli, 1983), which was developed specifically within a human rights framework to treat traumatized survivors of the Pinochet regime in Chile. NET procedure is two-fold; it places "focus on the habituation of emotional responding to reminders of the traumatic event experienced and the construction of a detailed narrative of the event and its consequences" (Neuner, Schauer, Klaschik, Karunakara, \& Elbert, , 2004, p. 580).

Given the extraordinary efforts of the United States to silence the Guantánamo prisoners, telling their stories may have particular power, although the ability to 
share torture details through legal mail may now be curtailed, as mentioned above.

Mahmadou Ould Slahi wrote his Guantánamo Diary through short declassified statements over a period of years, to express his experiences at Guantánamo and elsewhere. Ammar al Baluchi has had a number of statements regarding his experiences declassified, allowing him to tell parts of his story, albeit in a fragmented way (Amnesty International, 2017). Abu Zubaydah, through his attorney, has discussed his interest in describing part of his experience through courtroom testimony, although his most recent effort to testify did not succeed (Rosenberg, 2017).

Some possibility may also exist for treatment by correspondence, if the rule regarding detainee statements was once again changed such that they were subject to "public" release after declassification.

Although many treatment modalities require a personal connection between therapist and patient, it might be possible to provide treatment through guided self-help. For example, control-focused behavioral treatment is designed for implementation outside traditional therapy channels, and might present a possible vehicle for treatment (Başoğlu \& Mineka 1992; Başoğlu \& Şalcioğlu 2011). The correspondence involved in treatment would necessarily be slow, but could be carried out under the existing security structure at Guantánamo.

\section{Conclusion}

By adopting a policy of torture followed by imprisonment, the United States has created a terrible conundrum for itself. It has a legal, moral, and ethical responsibility to provide access to rehabilitation for torture survivors, but is instead imprisoning them indefinitely and subjecting them to conditions and restrictions which make such rehabilitation almost impossible. The United States has constructed a security regime which prevents its military medical care providers from effectively treating prisoners seeking rehabilitation, and bars almost all other qualified professionals from offering and providing such rehabilitation service to those prisoners. Rehabilitation for survivors of torture and CIDT at Guantánamo will require rethinking traditional models of treatment to work around the United States' current regulation and policies - or humanitarian transfer of detainees to countries that will provide such treatment. 
References

Amnesty International. (2017, January 10). USA broken promises: Failure to close Guantánamo is part of a deeper human rights deficit. Amnesty International Publications.

Apuzzo, M., Fink, S., \& Risen, J. (2016, October 8)

How U.S. Torture Left a Legacy of Damaged Minds. The New York Times. Retrieved from https://www.nytimes.com/2016/10/09/world/ciatorture-Guantánamo -bay.html?_r=0

Başoğlu, M. \& Şalcioğlu, E. (2011) A Mental Healthcare Model for Mass Trauma Survivors: Control-Focused Behavioral Treatment of Earthquake, War and Torture Trauma. Cambridge.

Başoğlu, M. \& Mineka, S. (1992) The role of uncontrollable and unpredictable stress in posttraumatic stress responses in torture survivors. Torture and its Consequences: Current Treatment Approaches. Cambridge.

Biswas, S., \& Zalloua, Z. A. (2011). Torture: Power, Democracy, and the Human Body. University of Washington Press.

Bloche, M.G., and Marks, J.H. (2005). Doctors and Interrogators at Guantánamo Bay. New England Fournal of Medicine, 353, 6-8.

Bufacchi, V., \& Arrigo, J. (2006). Torture, Terrorism and the State: a Refutation of the Ticking-Bomb Argument. Fournal of Applied Philosophy, 23(3), 355-373.

Bradbury, S. (2005a). Memorandum for John Rizzo re application of 18 USC SS $2340-2340$ A to certain techniques that may be used in the interrogation of a high value $\mathrm{Al}$ Qaeda detainee. Retrieved from https://www.therenditionproject. org.uk/pdf/PDF $\% 2016 \% 20$ [Bradbury\%20 Memo\%20to\%20Rizzo\%20Certain\%20Techniques $\% 2010 \% 20$ May\%20200.pdf.

Bradbury, S. (2005b). Memorandum for John Rizzo re application of 18 USC $\int \S 2340-2340 A$ to the combined use of certain techniques in the interrogation of high value $\mathrm{Al}$ Qaeda detainees.

Bybee, J. (2002, Aug. 1). Memorandum for Alberto Gonzales re; standards of conduct for interrogation under 18 USC SS 2340-2340A. Retrieved from http://www.washingtonpost. $\mathrm{com} / \mathrm{wp}$-srv/nation/documents/dojinterrogationmemo20020801.pdf.

Bybee, J. (2002, Aug. 1). Memorandum for John Rizzo re interrogation of an Al Qaeda operative. Retrieved from https://www.justice.gov/ sites/default/files/olc/legacy/2010/08/05/memobybee2002.pdf.

Campbell, T.A. (2007). Psychological assessment, diagnosis, and treatment of torture survivors: A review. Clinical Psychology Review, 27, 628-641.
Charney, D. S., Deutch, A. Y., Krystal, J. H., Southwick, S. M., \& Davis, M. (1993). Psychobiologic mechanisms of posttraumatic stress disorder. Archives of general psychiatry, 50(4), 294-305.

Chlopak, E. (2002). Dealing with the detainees at Guantánamo Bay: Humanitarian and human rights obligations under the Geneva Conventions. Human Rights Brief, 9(3), 2.

Central Intelligence Agency. (2004). CIA memo: Background paper on CIA's combined use of interrogation techniques. ACLU FOIA released (2009).

Cienfuegos, A. J., \& Monelli, C. (1983). The testimony of political repression as a therapeutic instrument. American fournal of Orthopsychiatry, 53(1), 43-51.

The Constitution Project. (2013, March). The Report of the Task Force on Detainee Treatment. Retrieved from https://detaineetaskforce.org/.

Convention Against Torture and Other Cruel, Inhuman or Degrading Treatment or Punishment. (2012, November 19).

Office of the High Commissioner of Human Rights, Committee Against Torture, General Comment No. 3. United Nations Treaty Series (2012).

Danner, M. (2009). US torture: Voices from the black sites. The New York Review of Books, 9.

Elbert, T., Schauer, M., Ruf, M., Weierstall, R., Neuner, F, Rockstroh, B., \& Jonghöfer, M. (2011). The tortured brain: Imaging neural representations of traumatic stress experiences using RSVP with affective pictorial stimuli. Zeitschrift für Psychologie/fournal of Psychology, 219, 167174.

Engstrom, D.W. \& Okamura, A. (2004). Working with Survivors of Torture: Approaches to Helping. Families in Society: The fournal of Contemporary Social Services, 85, 301-309.

Eisenberg, S. (2009). Guantánamo Bay: Redefining cruel and unusual. NEULF, 1, 125.

Fadiman, A. (2012). The spirit catches you and you fall down: A Hmong child, her American doctors, and the collision of two cultures. Macmillan.

Higson-Smith, C. (2015). Updating the estimate of refugees resettled in the United States who have suffered torture. Center for Victims of Torture.

Iacopino, V. \& Xenakis, S.N. (2011). Neglect of Medical Evidence of Torture in Guantánamo Bay: A Case Series. PLoS Medicine. Retrieved from https://doi.org/10.1371/journal.pmed.1001027

Kennedy, C. H., Malone, R. C., \& Franks, M. J. (2009). Provision of mental health services at the detention hospital in Guantánamo Bay. Psychological Services, 6(1), 1.

Khalifa, N., \& Hardie, T. (2005). Possession and jinn. 
Fournal of the Royal Society of Medicine, 98(8), 351-353.

Khalifa, N., Hardie, T., Latif, S., Jamil, I., \& Walker, D. M. (2011). Beliefs about Jinn, black magic and the evil eye among Muslims: age, gender and first language influences. International fournal of $\mathrm{Cul}$ ture and Mental Health, 4(1), 68-77.

Khalili, L. (2012). Time in the Shadows: confinement in counterinsurgencies. Stanford University Press.

Kira, I.A. (2002). Torture Assessment and Treatment: The Wraparound Approach. Traumatology, 8, 61-90.

Klasfeld, A. (2014, June 19). 'Genies' Cited In OnceSecret Brief on Wheelchair Ban at Guantanamo. Courthouse News. Retrieved from https://www. courthousenews.com/genies-cited-in-oncesecret-briefon-wheelchair-ban-at-guantanamo/

McCarthy, T. (2016, February 7). Donald Trump: I'd bring back 'a hell of a lot worse than waterboarding.' The Guardian. Retrieved from https://www.theguardian.com/us-news/2016/ $\mathrm{feb} / 06 /$ donald-trump-waterboarding-republicandebate-torture

McCoy, A. W. (2012). Torture and impunity: The US doctrine of coercive interrogation. University of Wisconsin Pres.

McColl, H., Higson-Smith, C., Gjerding, S., Omar, M. H., Rahman, B. A., Hamed, M., \& LowShang, C. (2010). Rehabilitation of torture survivors in five countries: common themes and challenges. International journal of mental health systems, 4(1), 16.

Mckenna Longacre, M. M., Silver-Highfield, E., Lama, P., \& Grodin, M. A. (2012). Complementary and alternative medicine in the treatment of refugees and survivors of torture: a review and proposal for action. Torture, 22(1), 38-57.

Memorandum of Agreement Between the Department of Defense (DOD) and the Central Intelligence Agency (CIA) Concerning the Detention by DOD Of Certain Terrorists at a Facility at Guantánamo Bay Naval Station (2006), FOIA Released 6541712 (2016), Retrieved from CIA Reading Room, https://www.cia.gov/library/readingroom/document $/ 6541712$

Mitchell, J. (2016). Enhanced Interrogation. Crown Forum, USA.

Mollica, R. F., \& Caspi-Yavin, Y. (1991). Measuring torture and torture-related symptoms. Psychological Assessment: A fournal of Consulting and Clinical Psychology, 3(4), 581.

Montgomery, E., \& Patel, N. (2011). Torture rehabilitation: Reflections on treatment outcome studies. Torture, 21(2), 141-5.

National Commission on Terrorist Attacks. (2004). The
9/11 commission report: Final report of the National Commission on Terrorist Attacks upon the United States. New York:W.W. Norton.

Neuner, F., Schauer, M., Klaschik, C., Karunakara, U., \& Elbert, T. (2004). A comparison of narrative exposure therapy, supportive counseling, and psychoeducation for treating posttraumatic stress disorder in an African refugee settlement. Fournal of consulting and clinical psychology, 72(4), 579.

Oosterhoff, P., Zwanikken, P., \& Ketting, E. (2004). Sexual torture of men in Croatia and other conflict situations: an open secret. Reproductive health matters, 12(23), 68-77.

Penal Reform International (2013, July). Rehabilitation support for survivors of torture: A case study: Freedom from Torture Rehabilitation Model. Retrieved from https://www.penalreform.org/resource/case-study-freedom-torturerehabilitation-model/

Pope, K.S. (2012). Psychological assessment of torture survivors: Essential steps, avoidable errors, and helpful resources. International fournal of Law and Psychiatry 35, 418-426.

Rosenberg, C. (2016, October 25). Guantánamo by the Numbers. The Miami Herald. Retrieved from http://www.miamiherald.com/news/ nation-world/world/americas/Guantánamo /article2163210.html

Rosenberg, C. (2008, February 7). Platinum captives held at off-limits Gitmo camp. The Miami Herald. Retrieved from http://www.miamiherald. com/news/nation-world/world/americas/Guantánamo /article1932471.html

Rosenberg, C. (2016, February 24). Alleged 9/11 plotter testifies: Guantánamo noises, vibrations are real, they drugged me for protesting. The Miami Herald. Retrieved from http://www.miamiherald.com/news/nation-world/world/americas/Guantánamo /article62287467.html

Rosenberg, C. (2017, May 18). Abu Zubaydah chooses not to testify at Guantánamo war court. Retrieved from http://www.miamiherald.com/ news/nation-world/world/americas/Guantánamo /article $151445502 . h t m l$

Quiroga, J., \& Jaranson, J. M. (2005). Politically-motivated torture and its survivors. Torture, 15, 2-3.

Ramstack, T. (2013, December 19). Judge orders sanity evaluation for accused $9 / 11$ conspirator. Reuters. Retrieved from http://www.reuters. com/article/us-usa-Guantánamo -idUSBRE9BIOWV20131219

Savage, C. (2017, March 17). C.I.A. Torture Left Scars on Guantánamo Prisoner's Psyche for Years. The New York Times. Retrieved from 
https://www.nytimes.com/2017/03/17/us/politics/ Guantánamo -bay-abd-al-rahim-al-nashiri.html Sayed, M.A. (2003). Conceptualization of mental illness within Arab cultures: Meeting challenges in cross-cultural settings. Social Behavior and Personality: an international journal, 31(4), 333-341.

Scarry, E. (1985). The body in pain: The making and unmaking of the world. Oxford University Press, USA.

Senate Select Committee on Intelligence ("SSCI"). (2014, December 9). Executive Summary of the Committee Study of the Central Intelligence Agency's Rendition, Detention, and Interrogation Program. Retrieved from https://www. feinstein.senate.gov/public/index.cfm/senateintelligence-committee-study-on-cia-detentionand-interrogation-program.

Serrano, R. A. (2014, December 10). Senate report on CIA torture could aid terrorism suspects in court. Los Angeles Times. Retrieved from http://www.latimes.com/world/middleeast/la-fgtorture-gitmo-20141211-story.html

Sveaass, N. (2013, May 8). Gross human rights violations and reparation under international law: approaching rehabilitation as a form of reparation. European fournal of Psychotraumatology, 4, 10.3402/ejpt.v4i0.17191. Retrieved from http:// doi.org/10.3402/ejpt.v4i0.17191.

United States District Court of the District of Columbia, Petitioner's Notice of Filing of Expert Report of Stephen N. Xenakis, M.D., L.L.C. (2014, September 15). Retrieved from www.miamiherald.com/news/nation-world/world/americas/ Guantánamo /article2524292.ece/binary/The\%20 retired $\% 20$ Army $\% 20$ psychiatrist $\% 27 \mathrm{~s} \% 20$ report $\% 20$ to $\% 20$ the $\% 20$ court.

United States Military Commission, Guantánamo Bay. (2013, February 16). AE200II Order to Defense Motion to Dismiss Because Amended Protective Order \#1 Violates the Convention Against Torture. Retrieved from http://www. mc.mil/Portals/0/pdfs/KSM2/KSM $\% 20 I I \% 20$ (AE200II).pdf

United States Military Commission, Guantánamo Bay. (2016, February 24). United States v. Khalid Shaikh Mohammad, et al., Testimony of Ramzi bin al Shibh. Retrieved from http://www. mc.mil/Portals/0/pdfs/KSM2/KSM\%20II\%20 (TRANS24Feb2016-AM1).pdf.

United States Military Commission, Guantánamo Bay. (2016, June 2).

United States v. Khalid Shaikh Mohammad, et al., Testimony of Guleed Hassan Dourad. Retrieved from http://www.mc.mil/Portals/0/pdfs/KSM2/ KSM\%20II\%20(TRANS2June2016-AM1).pdf.

United States Military Commission, Guantánamo
Bay. (2016, September 7). AE448 Mr. al Baluchi's Motion to Remove "High Value Detainee" Designation.

United States Military Commission, Guantánamo Bay. (2013, February 16). AE200II Order to Defense Motion to Dismiss Because Amended Protective Order \#1 Violates the Convention Against Torture.

Walsh, P.M., VADM. (2009, February 23). Guantánamo Bay Investigation Report. C-SPAN. Arlington, VA: Pentagon Briefing Room. Retrieved from https://www.c-span.org/video/?284246-1/ Guantánamo -bay-investigation-report 